\title{
Prevention of epileptogenesis as a future strategy for the treatment of epilepsy
}

\author{
A. Bragin ${ }^{1}$
}

Epilepsy affects more than 70 million people worldwide. From 30 to $40 \%$ of the patients are resistant to existing medication. This paper describes the current state of the treatment of epilepsy and proposes a future approach to preventative treatment at earlier stages of epileptogenesis. For preventative treatment biomarkers are needed that predict the development of epilepsy at its earlier stages. Pathological high frequency oscillations are the only acceptable biomarker of epileptogenesis. However, the main limitation of this biomarker is the necessity of implanting of recording electrodes. The search for noninvasive biomarkers of epileptogenesis is one of the hot topics in epilepsy research. There are two potentially interesting directions in this area: search for inflammatory biomarkers in the peripheral blood and analysis of different parameters of imaging methods. In this paper we present approaches for identification of potential epileptogenesis biomarkers by magnetic resonance imaging. Some of magnetic resonance imaging parameters correlate with the existence of pathological high frequency oscillations, may indirectly reflect ongoing inflammation process in the brain and be potential biomarkers of epileptogenesis.

Key words: epilepsy, pathological high frequency oscillations, biomarkers of epileptogenesis, preventative treatment

For citation: Bragin A. Prevention of epileptogenesis as a future strategy for the treatment of epilepsy. Almanac of Clinical Medicine. 2019;47(7):614-22. doi: 10.18786/2072-0505-2019-47-028.

Received 19 June 2019; accepted 24 June 2019; published online 9 July 2019

\section{Epilepsy from epileptic neurons to the multifactorial disease}

Each year in the U.S. approximately 150,000 people develop epilepsy [1-3]. In spite of tremendous success in our understanding of its neuronal and molecular mechanisms, from 30 to $40 \%$ of patients with epilepsy are resistant to current medical treatments [4-7]. Pharmacoresistant epilepsy is a major health burden worldwide $[8,9]$. Within the last 30 years more than 20 new antiepileptic drugs have been introduced to the clinic, however, to the big disappointment of scientists and clinicians the success in the treatment of patients with epilepsy increased only by $2-3 \%$ [10-13].

The overarching hypothesis in electrophysiology during the last century was that the epileptic brain consists of a certain number of epileptic neurons with altered properties of receptors and ion channels. A countless number of experiments and publications were in line with this hypothesis, and altered properties of many receptors and channels were discovered in epileptic brain. All new antiepileptic drugs were designed based on these data targeting one or another channel or receptor with the hope that it would stop seizures. The low effectiveness of all new antiepileptic drugs indicated that altered properties at the molecular level are only a part of problems in the epileptic brain. One of the reasons for the low efficiency of the
Anatol Bragin - PhD, DSci, Department of Neurology'; ORCID: https:// orcid.org/0000-00031207-8481

$\square 710$ Westwood Plaza, Los Angeles, CA, 90095, USA.

E-mail: abragin @mednet.ucla.edu

'David Geffen Medical School at University of California, Los Angeles: 710 Westwood Plaza, Los Angeles, CA, 90095, USA old and new antiepileptic drugs was the expectation that we could control seizure activity by modifying the activity of a certain "magic" channels or receptors. In reality, the deeper we investigate mechanisms of epilepsy, the more we see the complicated nature of the disease. The second issue, complicating the process of epilepsy treatment, was lack of understanding that by the time a patient was visiting a doctor and reporting that he/she had had a seizure, the patient's brain had undergone a long complicated process of restructuring of brain circuitry prone to generate seizure activity and involving abnormalities in multiple channels and receptors both in neuronal and non-neuronal cells.

The current understanding is symbolized by the recognition that the epileptic brain is associated not only with the existence of neurons with altered membrane properties, but also with altered connections between them. Slowly this notion was transformed into recognition of the concept that epilepsy is a disease of neuronal networks.

Currently it is clear that epilepsy is a multifactorial disorder, involving formation of distributed neuronal networks [14-17], chronic inflammation [18-21], and the existence of a spectrum of psychological problems, such as anxiety, depression and cognitive impairment [22]. 
Cognitive performance such as learning, memory and decision making depends on the coordinated activity of multiple brain areas, where hippocampus and prefrontal cortex play key roles [23-25]. These brain areas are also part of distributed neural systems underlying anxiety, emotion and motivation [26].

There is a growing need to understand the role of inflammation during epileptogenesis, but so far no reliable inflammatory biomarker of epileptogenesis has been found in animal models $[18,27,28]$. The Magnetic Resonance Imaging (MRI) approach may help to test inflammatory processes noninvasively and has a great potential as a biomarker of epileptogenesis. Several groups are using functional MRI (fMRI) to study the blood oxygen level dependent (BOLD) signal and changes in microstructure of brain areas under different experimental conditions [29-35]. According to some publications, fMRI and Diffusion Tensor Imaging (DTI) are promising indirect measures of inflammation processes and gliosis [36-38]. Although, fMRI does not directly reflect the level of inflammation, functional connectivity between brain areas, such as striatum and prefrontal cortex, decreases when the level of inflammation increases [39]. One of the DTI parameters, fractional anisotropy (FA), has been shown to correlate with the level of inflammation [4042], as well as microstructural integrity [40]. FA values both increase and decrease after traumatic brain injury (TBI) [43-45]. In patients with stroke FA values may be useful for prediction of cognitive functional outcomes [46] and can predict recovery of motor function after a stroke during the early subacute phase [47].

The combination of electrographic and imaging methods allows for identification of brain areas, where changes in metabolism and blood flow are associated with the formation of pathological neuronal networks. There is good correspondence between networks detected by electrographic and imaging methods [17, 48-50].

One of the ways to reduce the health burden of epilepsy is to prevent its development after specific epileptogenic insults. There are two key elements critical to the development of preventative therapy: 1) a full understanding of the mechanisms of epileptogenesis and 2) the existence of clinically useful noninvasive biomarkers of epileptogenesis.

It is not clear whether all above mentioned changes at multiple levels observed in patients with epilepsy are related to seizure activity or whether they occur earlier and are long-lasting consequences of an initial brain injury which is invisible without special diagnostic tests that predict later epilepsy. Recognition of this in animal models of chronic epilepsy will allow investigation of their initial mechanisms and discover new targets for prevention of epileptogenesis, as well as behavioral candidates. A combination of electrophysiological, imaging and behavioral biomarkers could provide better diagnosis, better specificity and sensitivity for detection of the ongoing process of epileptogenesis.

It is likely that a profile of biomarkers will be required for most clinical applications in addition to electroencephalogram (EEG) [51], which will improve the accuracy of epilepsy prediction [52-57]. Compared to electrophysiological methods, MRI has higher spatial resolution and provides valuable contrasting of grey and white matter. Functional MRI and DTI can detect various progressive abnormalities after a brain injury in multiple brain areas $[54,58,59]$. There is a strong coherence between functional connectivity estimated by fMRI signal and changes in the FA map, as well as in structural connectivity estimated by DTI [60]. In addition, changes in the BOLD signal correlate with the energy of smoothed high frequency broadband signals recorded in electrophysiological experiments [61-63].

It is conceptually important to consider that, within the brain framework, there is an interconnectedness between different levels of brain activity, and a complex system where all levels interact with each other to generate emergent behaviors that can be reflected in specific functions, such as an EEG pattern, a metabolic process (as measured by fMRI), or a pathologic phenotype [64].

Considering multifactorial nature of epileptogenesis, it is tempting to find noninvasive biomarkers of epileptogenesis. It is crucial for designing of future clinical trials for prevention of epileptogenesis; recognizing this, the U.S. National Institutes of Health (NIH) several years ago began funding an international project for prevention of epileptogenesis, which involves multiple hospitals and laboratories from the USA, Finland and Australia (https://epibios.loni.usc.edu). This is a unique translational project, which is aimed to develop the first validated multimodal biomarker panel for preclinical and clinical anti-epileptogenesis trials.

\section{Pathological high frequency oscillations as a bridge for identification of noninvasive biomarkers of epileptogenesis}

This section will provide a short description of published and preliminary results of how the research team at the UCLA Seizure Disorder Center is trying to find biomarkers of epileptogenesis. The experiments described here are performed in conjunction with ongoing research of the EpiBios4Rx project.

Pathological high frequency oscillations and epilepsy In 1999 our laboratory discovered the existence of pathological high frequency oscillations (pHFOs) in 
the frequency range $250-500 \mathrm{~Hz}$ in the epileptic brain (Fig. 1) [65-67]. These oscillations where observed in epileptic animals, as well as in patients with temporal lobe epilepsy. We have shown that these oscillations are generated by local clusters of pathologically interconnected neurons (PIN-clusters) and reflect hypersynchronous bursts of population spikes generated predominantly by principal cells $[68,69]$. Later these data were confirmed in other laboratories in different types of epilepsy [70-75]. It was shown that pHFOs were associated with seizure onset zone, and complete surgical removal of brain areas generating pHFOs was followed by a complete disappearance of seizures [7678]. Currently this approach is used for pre-surgical localization of seizure onset zone in many hospitals in the USA, Canada and Europe.

Analysis of time of pHFOs occurrence after status epilepticus and traumatic brain injury showed that pHFOs occured much earlier than recurrent spontaneous seizures; their occurrence after a brain injury allows for prediction which animals would later develop and would not develop epilepsy $[79,80]$. We hypothesized that the process of epileptogenesis was associated with the formation of the network of PIN-clusters $[14,68]$. Clinical seizures occur when motor areas are involved in this PIN-clusters network (Fig. 2). So far pHFOs are the only acceptable biomarker of epileptogenesis. However, the primary limitation of this biomarker is that it requires invasive recordings of brain activity, which excludes it from being a potential diagnostic tool. There is a need for noninvasive biomarkers for easy identification of epileptogenesis and preventative treatment. Noninvasive imaging biomarkers would have a much greater translational value.

\section{Spatial and temporal distribution of high frequency oscillations during epileptogenesis after status epilepticus and TBI}

Recently, we found that epileptogenesis after TBI has electrographic characteristics similar to those in pilocarpine and kainic acid (KA) status epilepticus models [80]. As in the KA model [81], the occurrence of pHFOs within the first two weeks after TBI is a biomarker of epileptogenesis [80]. These pHFOs appeared in the group of animals that later developed epilepsy, and they occurred within the TBI core or perilesional area, which then propagated to other neighboring areas. We described that after TBI, in the group that later developed epilepsy, pHFOs occurred independently, as well as in association with spindle oscillations. They were nested in the troughs of spindle oscillations (Fig. 3) and associated with hypersynchronized discharges of multiunit activity (Fig. 3B and C). In these TBI experiments, only in rats that later developed epilepsy, an increase of normal

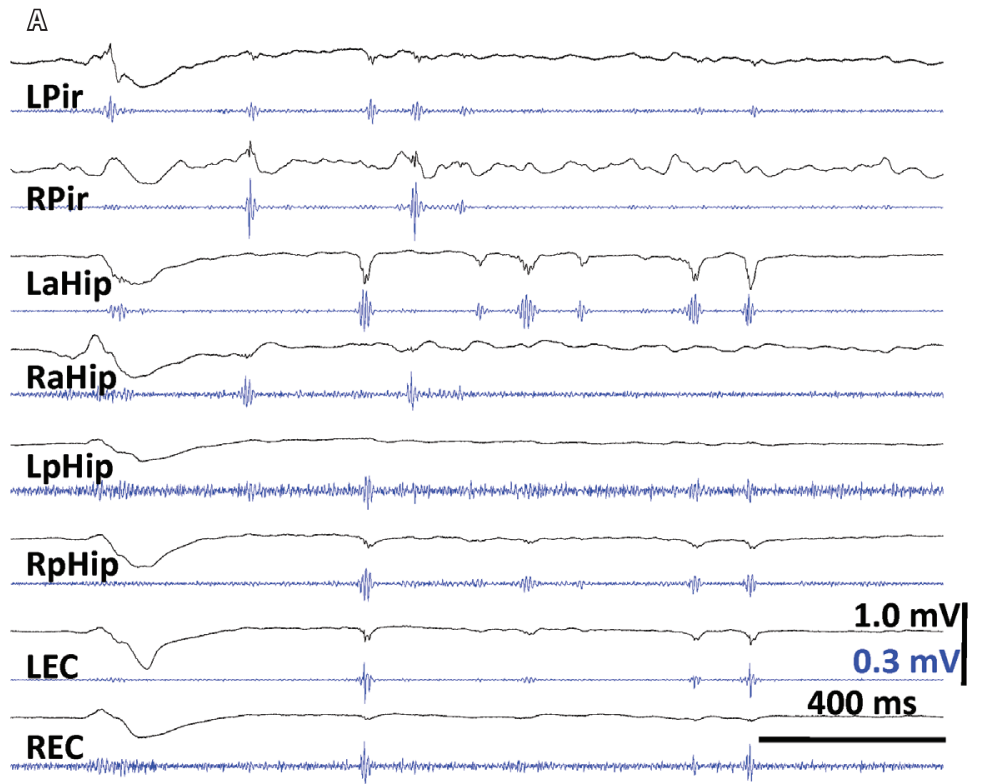

$$
\text { B }
$$
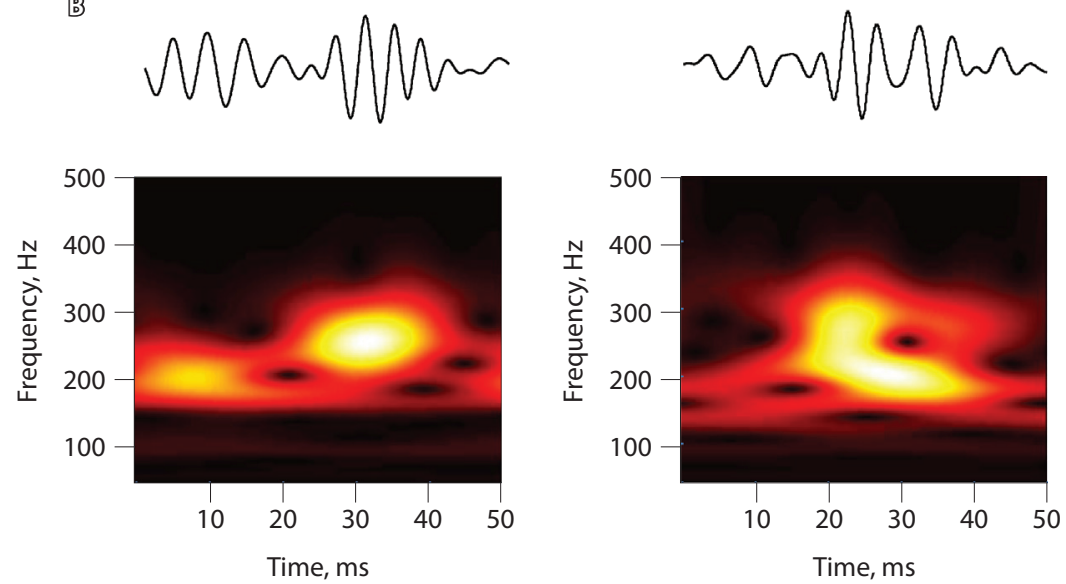

Fig. 1. Pathological high frequency oscillations in an epileptic rat. A. Example raw (black) and band pass $(100-500 \mathrm{~Hz}$ ) filtered data (blue) during the inter-ictal period recorded from various brain areas. B. Extended examples of pathological high frequency oscillations (top) and their time frequency plots (bottom); $L$ left, $R$ right, $a$ anterior, $p$ posterior, Pir piriform cortex, Hip hippocampus, EC entorhinal cortex

high frequency oscillations rate was observed in multiple brain areas, as was the occurrence of pHFOs. The occurrence of pHFOs outside of the lesioned hippocampus and outside of the TBI area supports the hypothesis of the formation of a PIN-cluster network during epileptogenesis [14, 68]. These PIN-clusters generate pHFOs, as a result of the hypersynchronization of neuronal discharges forming population spikes, maintain fast propagation of epileptiform activity and trigger seizures.

Correlation between pHFOs, PIN-cluster network formation and changes in other modalities of brain function and structure, such as alterations of intrinsic functional brain connectivity, malformation of local 


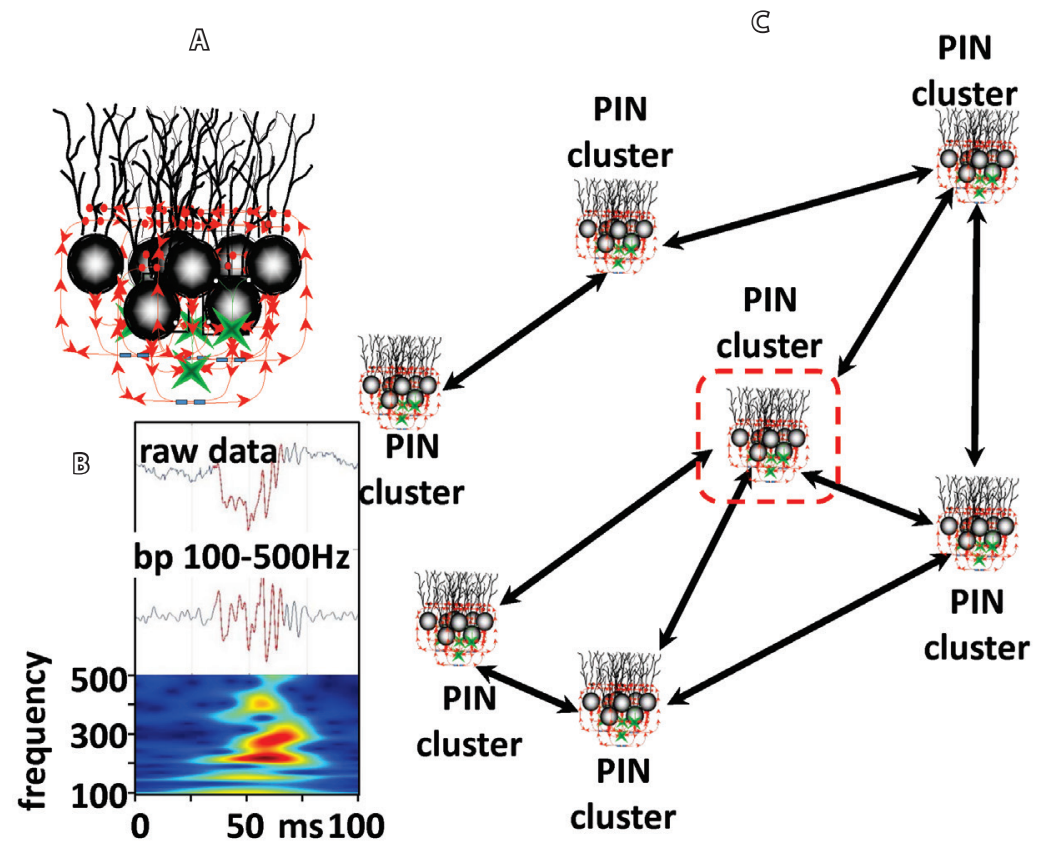

Fig. 2. A schematic presentation of a PIN-cluster (A). Grey, principal cells: green, interneurons. Red lines are abnormal connections between neurons with a PIN-cluster. B, examples of raw (top) band pass filtered (middle) and time frequency plot (bottom) of pathological high frequency oscillation. C, a schematic presentation of a PIN-cluster network. Dashed box is a lesion area
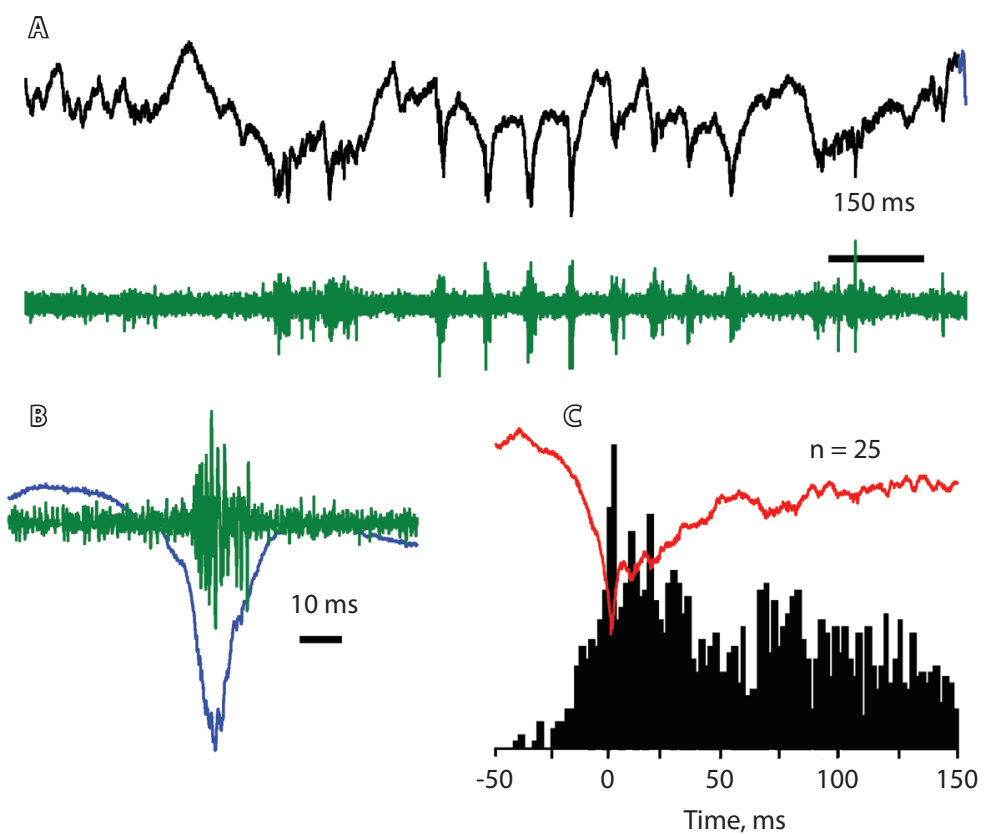

Fig. 3. Coupling of high frequency oscillations and hypersynchronized multiunit discharges with spindle activity in perilesional area 10 days after traumatic brain injury in the rat that later developed epilepsy. A. An example of single spindle oscillation. Black, raw data; green, band pass $(100-500 \mathrm{~Hz})$ filtered signal indicating high frequency oscillation activity. B. An example of a single spindle wave. $\boldsymbol{C}$. Perievent histogram triggered by the $1^{\text {st }}$ spindle event showing hypersynchronization of multiunit discharges with spindle events structure assemblies and reorganization of large-scale fiber track networks is a major challenge, because they may not be linear [64]. However, studies of such correlative connections should help to build bridges between different levels of brain activity in pathological conditions, such as epilepsy.

Currently the pathophysiology of epileptogenesis has been studied with electrographic methods; however these electrical patterns reflect multiple functional and structural disturbances that might be measured by MRI. Imaging methods have the capability to reveal 3D networks in the brain, while electrographic methods have high temporal, but limited spatial resolution.

\section{fMRI - electrographic correlates of epileptogenesis}

At present, the preliminary data on fMRI experiments pertain only to the KA-model of chronic epilepsy. This series of experiments was carried out in 11 rats. In all of these rats baseline fMRI data collection was performed one week before KA and the second fMRI screening was performed 10 days after the KA injection. Immediately after the second MRI, microelectrodes were implanted bilaterally in 8 brain regions: left (L) and right (R) anterior cingulate (LAC and RAC), prelimbic (LPC and RPC), motor cortex (LMC and RMC), thalamus (LTh and RTh) and hippocampus (LHP and RHP). Within this group valuable data were obtained from 9 rats; all of them became epileptic within 2-4 months. The baseline BOLD signal functional connectivity (FC) between LAC/RAC, LPC/RPC, LMC/RMC, LTL/RTL, anterior and posterior hippocampi (combined DG\&CA1 signals) was compared before and 10 days after the KA injection. In epileptic rats, we observed a decline of FC between certain brain areas (Fig. 4A) [p<0.0001] and an increase of FC within brain areas (the data values are not shown). Three days after the second fMRI scan, electrographic FC for the same brain areas was assessed on the basis of high gamma frequency band (HGFB), as described in several publications [61-63]. Similar to BOLD signal FC, the HGFB FC showed a concordant decrease between multiple brain areas (Fig. 4B) [p=0.011].

The agreement between the different measures of FC indicates that despite the recording of fMRI and electrographic signals 3 days apart, similar changes in FC were measured. This indicates the existence of consistent changes in the epileptic brain that promote (or maintain) the process of epileptogenesis. Comparing the correlation between BOLD and HGFB functional connectivity we found that during epileptogenesis there was an increase in BOLD-electrographic coupling (Fig. 5A vs B), associated with increased synchrony of multiunit discharges during HGFB events (Fig. 5C vs D). 


\section{DTI correlates of epileptogenesis}

Our analysis of in-vivo DTI data in 9 TBI rats showed both increases and decreases in FA values 2 weeks after TBI in different brain areas. However, in the major specific areas of interest (the hippocampus, prefrontal cortex and thalamus ipsilateral to TBI) FA was significantly increased in the hippocampus (Fig. 6A), but not in the prefrontal cortex and thalamus, compared to those in the sham-injured control. At the individual level, FA values both increased and decreased in different rats (Fig. 6B). Electrophysiological evaluation of these rats is still in progress and we predict that similar to the KA model, those rats in which FA was not changed significantly (Fig. 6B, black lines), will belong to the group with no subsequent epilepsy, while those with increased FA (Fig. 6B, green lines) will belong to the group that later develop epilepsy.

\section{Behavioral correlates of epileptogenesis}

These experiments were performed in 5 rats using the water-cheeseboard maze (WCBM) test (Fig. 7A). Two days before the behavioral experiments the rats were placed on the WCBM table, where all wells were filled with water, twice for 30 minutes to make them familiar with the WCBM environment.

After two days of water deprivation, the learning process experiments began, where only 4 wells were filled with water. The rats were placed in the starting box, the door was opened, and the rats were allowed to search for a well with a water. After finding all of them, the rats were returned to the start box and the procedure was repeated 10 times. The next day the procedures were repeated. All data were recorded and analyzed with "AnyMaze" software. In this task, we analyzed the level of anxiety, which was measured by the time required for the rat go from the start box to the first well with the water (Fig. 7. Time 1). The quality of cognitive performance (memory score) was estimated by the quality of remembering the spatial location of the remaining 3 water wells. It was estimated by measuring the time required for the rat to reach each of them, as well as by measuring the length of the path it took to reach each well and the time (Time 2+Time 3+Time 4). The memory score (MS) was calculated by the formula: $M S=\left(1-t \neg i / t_{b}\right) \times 100$, where $t \neg i$ is the time taken to complete the first task on the second experimental day and $t_{b}$ is the time taken to complete the last task on the first day.

During the test at the end of the second week after the KA injection there was an increase in anxiety in 3 rats and in 2 rats the anxiety level was lower than baseline (Fig. 7, $\mathrm{B}$, orange bars). The same rats that demonstrated higher anxiety, showed poor performance during the memory test (Fig. 7, B, green bars). The behavioral abnormalities in these 3 rats were associated with the occurrence
A

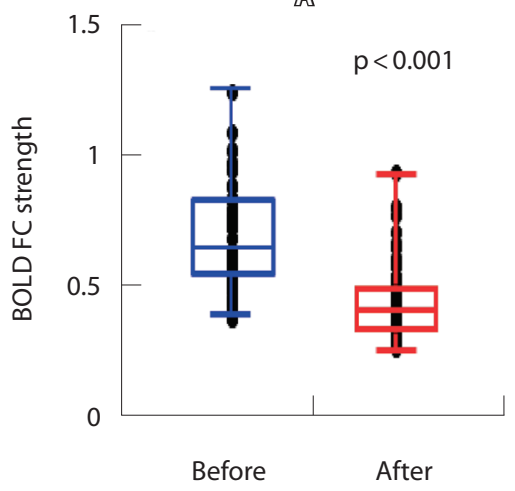

B

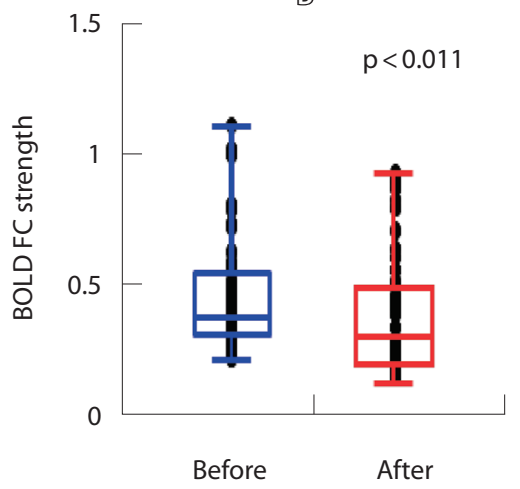

Fig. 4. Changes in functional connectivity before (blue) and after (red) kainic acid injection in E+ group measured by blood oxygen level dependent signal (A) and by HGFB (B). Dots represent each individual rat

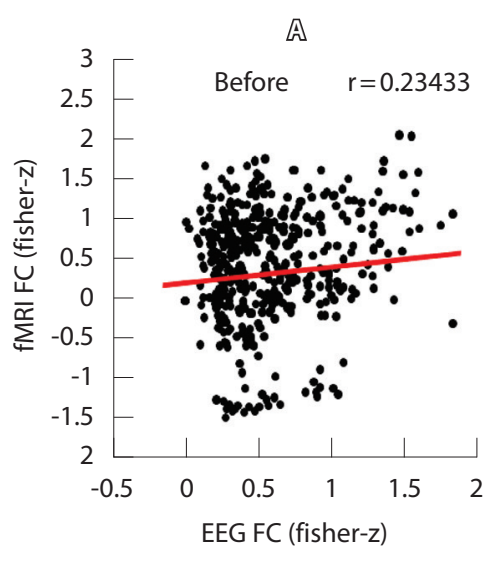

c

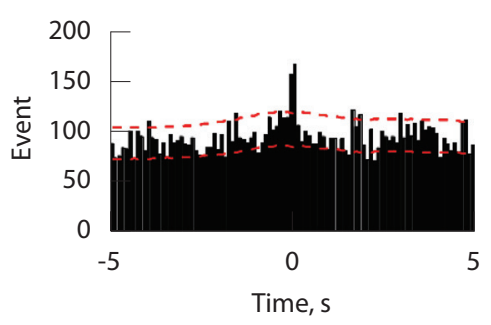

B

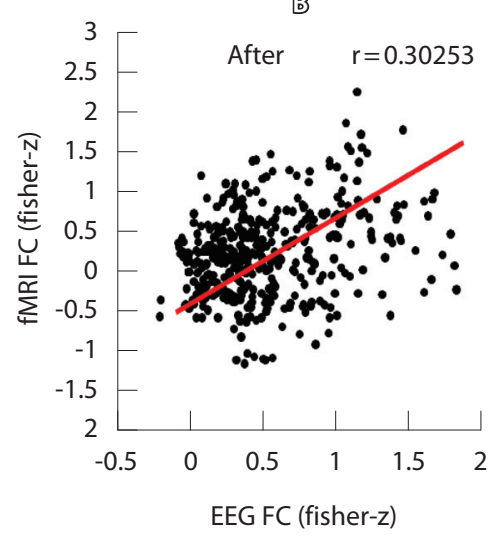

D

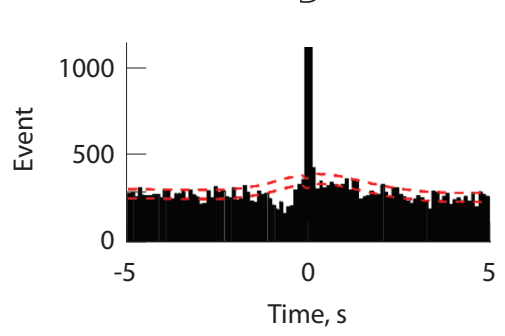

Fig. 5. A-B. Increased coupling between functional magnetic resonance imaging and HGFB functional connectivity during epileptogenesis. Synchrony of multiunit discharges during smoothed gamma events at baseline (C) and during epileptogenesis (D)

of pHFOs in the hippocampus and prefrontal cortex and the occurrence of spindles in the prefrontal cortex triggered by hippocampal pHFOs and later the occurrence of seizures within a 6 month period (data not shown).

\section{Summary}

The presented evidence indicates at the neuronal level that epileptogenesis is characterized by the appearance of distributed networks of pHFO generating neuronal 

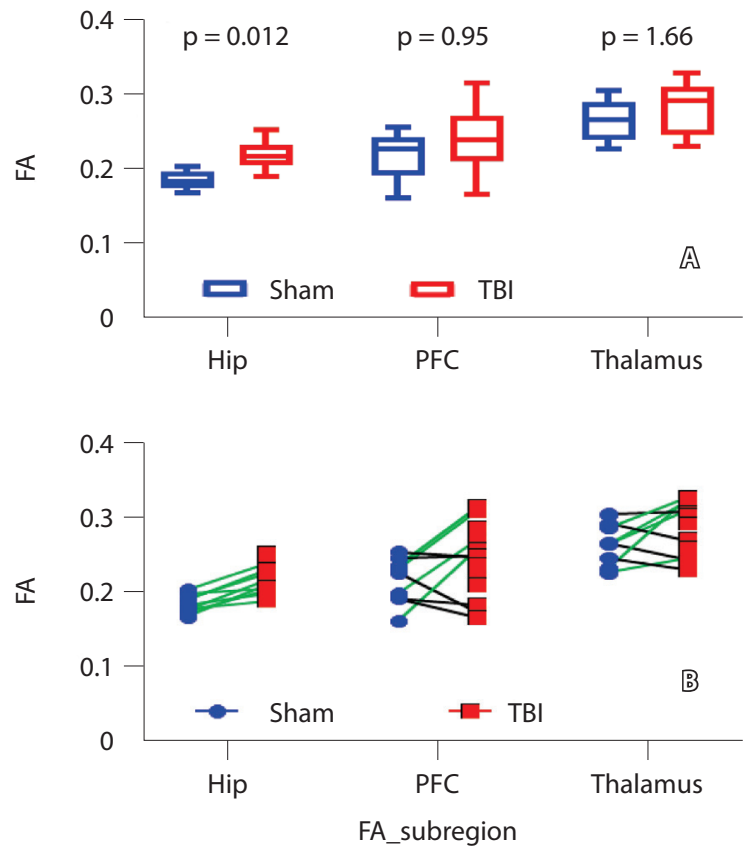

Fig. 6. Changes in fractional anisotropy (FA) values after traumatic brain injury (TBI) in three different brain areas. A. Average FA values in hippocampus (Hip), prefrontal cortex (PFC) and thalamus with standard deviation, and $p$ values on the top. $\mathbf{B}$. FA values in the same areas from individual 9 rats of the sham group (blue) and 9 rats of the TBI group (red)

clusters. These PIN clusters initially appear in the KA or TBI perilesional areas and spread towards other brain areas. Our data also illustrate that functional connectivity between different brain areas estimated by BOLD signals, as well as by electrographic signals (HGFB signal), decreases within the first two weeks after TBI in the group that later developed epilepsy, and that during epileptogenesis the coupling between BOLD and HGFB signals increases. In these preliminary experiments, we also found that FA value in some brain areas is increased in the animals that later developed epilepsy. We provide preliminary evidence that during epileptogenesis the brain undergoes consistent changes detectable by
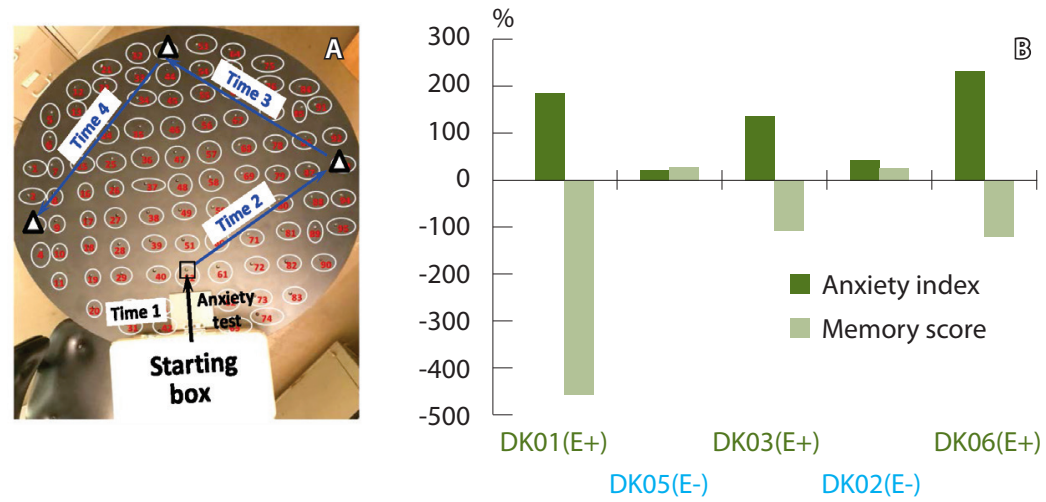

Fig. 7. A. Snapshot from the water-cheeseboard maze task experiment. The $1^{\text {st }}$ well from the starting box is indicated by the red arrow. Other wells with water are outlined by white squares and arrows. B. Anxiety index and memory score in the E+ group (red font) and the E- group (blue font) 2 weeks after the kainic acid injection

both electrographic and imaging methods. Although, electrophysiological patterns with increased synchrony of neuronal discharges leading to generation of pHFOs, as well as an increase in BOLD - HGFB coupling, might be expected to result in increased FC between different brain areas, we found FC to be decreased. Our preliminary explanation for this unexpected finding is that $\mathrm{pHFO}$ generate noisy signals disrupting the coherence between brain areas that exist under normal conditions, which results in reduced strength of functional connectivity between them. However, further data are required to explain or reject this hypothesis.

We find that simultaneously with a decrease in FC between neuronal networks, FA increases, and this may be related to heightened inflammatory processes that occur during this post-injury time. Although we do not yet understand the full relationship between electrographic and imaging processes, imaging may yield sensitive noninvasive biomarkers of epileptogenesis, eliminating the need for invasive recording of $\mathrm{pHFOs}$ for this purpose.

An increase in anxiety and cognitive decline occurring before the appearance of spontaneous seizures indicates that these parameters could be behavioral biomarkers of epileptogenesis. (\$)

\section{Additional information}

\section{Funding}

This study was supported by National Institutes of Health (NIH) grant NS065877.

\section{Conflict of interest}

The author declares no potential conflicts of interest with respect to the research, authorship, and/or publication of this article.

\section{References}

1. Kaiboriboon K, Bakaki PM, Lhatoo SD, Koroukian $\mathrm{S}$. Incidence and prevalence of treated epilepsy among poor health and low-income Americans. Neurology. 2013;80(21):1942-9. doi: 10.1212/WNL.0b013e318293e1b4.
2. Tang DH, Malone DC, Warholak TL, Chong J,

Armstrong EP, Slack MK, Hsu CH, Labiner DM.

Prevalence and Incidence of Epilepsy in an El-

derly and Low-Income Population in the Unit- ed States. J Clin Neurol. 2015;11(3):252-61. doi: 10.3988/jcn.2015.11.3.252.

3. Kim H, Thurman DJ, Durgin T, Faught E, Helmers S. Estimating epilepsy incidence and prevalence in the US pediatric population 
using nationwide health insurance claims data. J Child Neurol. 2016;31(6):743-9. doi: $10.1177 / 0883073815620676$

4. Elger CE. Pharmacoresistance: modern concept and basic data derived from human brain tissue. Epilepsia. 2003;44 Suppl 5:9-15. doi: 10.1046/j.1528-1157.44.s6.2.x.

5. Jamali S, Bartolomei $F$, Robaglia-Schlupp A, Massacrier A, Peragut JC, Régis J, Dufour $\mathrm{H}$, Ravid R, Roll P, Pereira S, Royer B, Roeckel-Trevisiol N, Fontaine M, Guye M, Boucraut J, Chauvel P, Cau P, Szepetowski P. Large-scale expression study of human mesial temporal lobe epilepsy: evidence for dysregulation of the neurotransmission and complement systems in the entorhinal cortex. Brain. 2006;129(Pt 3): 625-41. doi: 10.1093/brain/awl001.

6. Badawy RA, Macdonell RA, Berkovic SF, Newton MR, Jackson GD. Predicting seizure control: cortical excitability and antiepileptic medication. Ann Neurol. 2010;67(1):64-73. doi: 10.1002/ana.21806.

7. Doeser A, Dickhof G, Reitze M, Uebachs M, Schaub C, Pires NM, Bonifácio MJ, Soares-daSilva $\mathrm{P}$, Beck H. Targeting pharmacoresistant epilepsy and epileptogenesis with a dual-purpose antiepileptic drug. Brain. 2015;138(Pt 2): 371-87. doi: 10.1093/brain/awu339.

8. Begley $C E$, Famulari $M$, Annegers JF, Lairson DR, Reynolds TF, Coan S, Dubinsky S, Newmark ME, Leibson C, So EL, Rocca WA. The cost of epilepsy in the United States: an estimate from population-based clinical and survey data. Epilepsia. 2000;41(3):342-51. doi: 10.1111/j.1528-1157.2000.tb00166.x.

9. Kobau R, Zahran H, Thurman DJ, Zack MM, Henry TR, Schachter SC, Price PH; Centers for Disease Control and Prevention (CDC). Epilepsy surveillance among adults - 19 States, Behavioral Risk Factor Surveillance System, 2005. MMWR Surveill Summ. 2008;57(6):1-20.

10. French JA, Gazzola DM. New generation antiepileptic drugs: what do they offer in terms of improved tolerability and safety? Ther Adv Drug Saf. 2011;2(4):141-58. doi: $10.1177 / 2042098611411127$

11.Löscher W, Schmidt D. Modern antiepileptic drug development has failed to deliver: ways out of the current dilemma. Epilepsia. 2011;52(4):657-78. doi: 10.1111/j.15281167.2011.03024.x

12. Simonato $M$, Löscher W, Cole AJ, Dudek FE, Engel J Jr, Kaminski RM, Loeb JA, Scharfman H, Staley KJ, Velíšek L, Klitgaard H. Finding a better drug for epilepsy: preclinical screening strategies and experimental trial design. Epilepsia. 2012;53(11):1860-7. doi: 10.1111/j.1528-1167.2012.03541.x.

13. Androsova G, Krause R, Borghei $M$, Wassenaar $M$, Auce $P$, Avbersek $A$, Becker $F$, Berghuis B, Campbell E, Coppola A, Francis B, Wolking S, Cavalleri GL, Craig J, Delanty N, Koeleman BPC, Kunz WS, Lerche H, Mar- son AG, Sander JW, Sills GJ, Striano P, Zara F, Sisodiya SM, Depondt C; EpiPGX Consortium. Comparative effectiveness of antiepileptic drugs in patients with mesial temporal lobe epilepsy with hippocampal sclerosis. Epilepsia. 2017;58(10):1734-41. doi: 10.1111/epi.13871.

14. Bragin A, Wilson CL, Engel J Jr. Chronic epileptogenesis requires development of a network of pathologically interconnected neuron clusters: a hypothesis. Epilepsia. 2000;41 Suppl 6:S144-52. doi: 10.1111/j.1528-1157.2000. tb01573.x.

15. Blumenfeld $\mathrm{H}$. From molecules to networks: cortical/subcortical interactions in the pathophysiology of idiopathic generalized epilepsy. Epilepsia. 2003;44 Suppl 2:7-15. doi: 10.1046/ j.1528-1157.44.s11.3.x.

16. Feldt Muldoon S, Soltesz I, Cossart R. Spatially clustered neuronal assemblies comprise the microstructure of synchrony in chronically epileptic networks. Proc Natl Acad Sci U S A. 2013;110(9): 3567-72. doi: 10.1073/pnas.1216958110.

17. Blumenfeld $H$. What is a seizure network? Long-range network consequences of focal seizures. Adv Exp Med Biol. 2014;813:63-70. doi: 10.1007/978-94-017-8914-1_5.

18. Aronica E, Crino PB. Inflammation in epilepsy: clinical observations. Epilepsia. 2011;52 Suppl 3:26-32. doi: 10.1111/j.15281167.2011.03033.x.

19. Friedman A, Dingledine R. Molecular cascades that mediate the influence of inflammation on epilepsy. Epilepsia. 2011;52 Suppl 3:33-9. doi: 10.1111/j.1528-1167.2011.03034.x.

20. Devinsky O, Vezzani A, Najjar S, De Lanerolle NC, Rogawski MA. Glia and epilepsy: excitability and inflammation. Trends Neurosci. 2013;36(3):174-84. doi: 10.1016/j. tins.2012.11.008.

21. Holtman L, van Vliet EA, Aronica E, Wouters D, Wadman WJ, Gorter JA. Blood plasma inflammation markers during epileptogenesis in post-status epilepticus rat model for temporal lobe epilepsy. Epilepsia. 2013;54(4):589-95. doi: 10.1111/epi.12112.

22. Scott AJ, Sharpe L, Hunt C, Gandy M. Anxiety and depressive disorders in people with epilepsy: A meta-analysis. Epilepsia. 2017;58(6): 973-82. doi: 10.1111/epi.13769.

23. Euston DR, Gruber AJ, McNaughton BL. The role of medial prefrontal cortex in memory and decision making. Neuron. 2012;76(6):1057-70. doi: 10.1016/j.neuron.2012.12.002.

24. Rajasethupathy $P$, Sankaran S, Marshel JH, Kim CK, Ferenczi E, Lee SY, Berndt A, Ramakrishnan C, Jaffe A, Lo M, Liston C, Deisseroth $\mathrm{K}$. Projections from neocortex mediate top-down control of memory retrieval. $\mathrm{Na}$ ture. 2015;526(7575):653-9. doi: 10.1038/nature 15389

25. Khodagholy D, Gelinas JN, Buzsáki G. Learning-enhanced coupling between ripple oscillations in association cortices and hippocam- pus. Science. 2017;358(6361):369-72. doi 10.1126/science.aan6203.

26. Morgane PJ, Galler JR, Mokler DJ. A review of systems and networks of the limbic forebrain/ limbic midbrain. Prog Neurobiol. 2005;75(2): 143-60. doi: 10.1016/j.pneurobio.2005.01.001.

27. Kobow K, Auvin S, Jensen F, Löscher W, Mody I, Potschka $H$, Prince $D$, Sierra $A$, Simonato $M$ Pitkänen A, Nehlig A, Rho JM. Finding a better drug for epilepsy: antiepileptogenesis targets. Epilepsia. 2012;53(11):1868-76. doi: 10.1111/j.1528-1167.2012.03716.x.

28. van Vliet EA, Dedeurwaerdere S, Cole AJ, Friedman $\mathrm{A}$, Koepp MJ, Potschka $\mathrm{H}$, Immonen $\mathrm{R}$ Pitkänen A, Federico P. WONOEP appraisal: Imaging biomarkers in epilepsy. Epilepsia. 2017;58(3):315-30. doi: 10.1111/epi.13621.

29. Laitinen T, Sierra A, Pitkänen A, Gröhn O. Diffusion tensor MRI of axonal plasticity in the rat hippocampus. Neuroimage. 2010;51(2):52130. doi: 10.1016/j.neuroimage.2010.02.077

30. Coras R, Milesi G, Zucca I, Mastropietro A, Scotti A, Figini M, Mühlebner A, Hess A, Graf W, Tringali G, Blümcke I, Villani F, Didato G, Frassoni C, Spreafico R, Garbelli R. 7T MRI features in control human hippocampus and hippocampal sclerosis: an ex vivo study with histologic correlations. Epilepsia. 2014;55(12):2003-16. doi: 10.1111/epi.12828.

31. Sierra A, Laitinen T, Gröhn O, Pitkänen A. Diffusion tensor imaging of hippocampal network plasticity. Brain Struct Funct. 2015;220(2):781801. doi: 10.1007/s00429-013-0683-7.

32. Modo M, Hitchens TK, Liu JR, Richardson RM Detection of aberrant hippocampal mossy fiber connections: Ex vivo mesoscale diffusion MRI and microtractography with histological validation in a patient with uncontrolled temporal lobe epilepsy. Hum Brain Mapp. 2016;37(2):780-95. doi: 10.1002/hbm.23066.

33. Khoo HM, Hao Y, von Ellenrieder N, Zazubovits N, Hall J, Olivier A, Dubeau F, Gotman J. The hemodynamic response to interictal epileptic discharges localizes the seizure-onset zone. Epilepsia. 2017;58(5):811-23. doi: 10.1111/ epi.13717.

34. Khoo HM, von Ellenrieder $\mathrm{N}$, Zazubovits $\mathrm{N}$, Dubeau F, Gotman J. Epileptic networks in action: Synchrony between distant hemodynamic responses. Ann Neurol. 2017;82(1):57-66. doi: 10.1002/ana.24973.

35. Pittau F, Ferri L, Fahoum F, Dubeau F, Gotman J. Contributions of EEG-fMRI to assessing the epileptogenicity of focal cortical dysplasia. Front Comput Neurosci. 2017:11:8. doi: 10.3389/fncom.2017.00008.

36. Dev SI, Moore RC, Soontornniyomkij B, Achim CL, Jeste DV, Eyler LT. Peripheral inflammation related to lower $\mathrm{fMRI}$ activation during a working memory task and resting functional connectivity among older adults: a preliminary study. Int J Geriatr Psychiatry. 2017;32(3): 341-9. doi: 10.1002/gps.4482. 
37. Budde MD, Janes L, Gold E, Turtzo LC, Frank JA. The contribution of gliosis to diffusion tensor anisotropy and tractography following traumatic brain injury: validation in the rat using Fourier analysis of stained tissue sections. Brain. 2011;134(Pt 8):2248-60. doi: 10.1093/ brain/awr161.

38. Mihai PG, Otto M, Domin M, Platz T, Hamdy S, Lotze M. Brain imaging correlates of recovered swallowing after dysphagic stroke: A fMRI and DWI study. Neuroimage Clin. 2016;12:1013-21. doi: 10.1016/j.nicl.2016.05.006.

39. Felger JC, Li Z, Haroon E, Woolwine BJ, Jung MY, Hu X, Miller AH. Inflammation is associated with decreased functional connectivity within corticostriatal reward circuitry in depression. Mol Psychiatry. 2016;21(10):1358-65. doi: 10.1038/mp.2015.168.

40. Alexander AL, Lee JE, Lazar M, Field AS. Diffusion tensor imaging of the brain. Neurotherapeutics. 2007;4(3):316-29. doi: 10.1016/j. nurt.2007.05.011.

41. MacKenzie-Graham AJ, Rinek GA, Avedisian A, Morales LB, Umeda E, Boulat B, Jacobs RE, Toga AW, Voskuhl RR. Estrogen treatment prevents gray matter atrophy in experimental autoimmune encephalomyelitis. J Neurosci Res. 2012;90(7):1310-23. doi: 10.1002/jnr.23019.

42. Hemanth Kumar BS, Mishra SK, Trivedi R, Singh S, Rana P, Khushu S. Demyelinating evidences in CMS rat model of depression: a DTI study at 7 T. Neuroscience. 2014;275:12-21. doi: 10.1016/j.neuroscience.2014.05.037.

43. Begonia MT, Prabhu R, Liao J, Whittington WR, Claude A, Willeford B, Wardlaw J, Wu R, Zhang S, Williams LN. Quantitative analysis of brain microstructure following mild blunt and blast trauma. J Biomech. 2014;47(15):3704-11. doi: 10.1016/j.jbiomech.2014.09.026.

44. Harris NG, Verley DR, Gutman BA, Sutton RL. Bi-directional changes in fractional anisotropy after experiment TBI: Disorganization and reorganization? Neuroimage. 2016;133:129-43. doi: 10.1016/j.neuroimage.2016.03.012.

45. Kikinis Z, Muehlmann M, Pasternak O, Peled S, Kulkarni P, Ferris C, Bouix S, Rathi $Y$, Koerte IK, Pieper S, Yarmarkovich A, Porter CL, Kristal BS, Shenton ME. Diffusion imaging of mild traumatic brain injury in the impact accelerated rodent model: A pilot study. Brain Inj. 2017;31(10):1376-81. doi: 10.1080/02699052.2017.1318450.

46. Koyama T, Domen K. Diffusion Tensor Fractional Anisotropy in the Superior Longitudinal Fasciculus Correlates with Functional Independence Measure Cognition Scores in Patients with Cerebral Infarction. J Stroke Cerebrovasc Dis. 2017;26(8):1704-11. doi: 10.1016/j.jstrokecerebrovasdis.2017.03.034.

47. Thomalla G, Glauche V, Koch MA, Beaulieu C, Weiller $C$, Röther J. Diffusion tensor imaging detects early Wallerian degeneration of the pyramidal tract after ischemic stroke. Neu- roimage. 2004;22(4):1767-74. doi: 10.1016/j. neuroimage.2004.03.041.

48. Gotman J. Epileptic networks studied with EEG-fMRI. Epilepsia. 2008;49 Suppl 3:42-51. doi: 10.1111/j.1528-1167.2008.01509.x.

49. Bettus G, Ranjeva JP, Wendling F, Bénar CG, Confort-Gouny S, Régis J, Chauvel P, Cozzone PJ, Lemieux L, Bartolomei F, Guye $M$. Interictal functional connectivity of human epileptic networks assessed by intracerebral EEG and BOLD signal fluctuations. PLoS One. 2011;6(5):e20071. doi: 10.1371/journal. pone.0020071.

50. Bertoglio D, Jonckers E, Ali I, Verhoye M, Van der Linden A, Dedeurwaerdere S. In vivo measurement of brain network connectivity reflects progression and intrinsic disease severity in a model of temporal lobe epilepsy. Neurobiol Dis. 2019;127:45-52. doi: 10.1016/j. nbd.2019.02.012.

51. Jozwiak S, Becker A, Cepeda C, Engel J Jr, Gnatkovsky V, Huberfeld G, Kaya M, Kobow K, Simonato M, Loeb JA. WONOEP appraisal: Development of epilepsy biomarkers - What we can learn from our patients? Epilepsia. 2017;58(6): 951-61. doi: 10.1111/epi.13728.

52. Mirsattari SM, Wang Z, Ives JR, Bihari F, Leung LS, Bartha R, Menon RS. Linear aspects of transformation from interictal epileptic discharges to BOLD fMRI signals in an animal model of occipital epilepsy. Neuroimage. 2006;30(4):1133-48. doi: 10.1016/j.neuroimage.2005.11.006.

53. Dubé CM, Ravizza $T$, Hamamura $M$, Zha $Q$ Keebaugh A, Fok K, Andres AL, Nalcioglu $O$ Obenaus A, Vezzani A, Baram TZ. Epileptogenesis provoked by prolonged experimental febrile seizures: mechanisms and biomarkers. J Neurosci. 2010;30(22):7484-94. doi: 10.1523/ JNEUROSCI.0551-10.2010

54. Parekh MB, Carney PR, Sepulveda H, Norman W, King M, Mareci TH. Early MR diffusion and relaxation changes in the parahippocampal gyrus precede the onset of spontaneous seizures in an animal model of chronic limbic epilepsy. Exp Neurol. 2010;224(1):258-70. doi: 10.1016/j.expneurol.2010.03.031.

55. Dedeurwaerdere S, Shultz SR, Federico P, Engel J Jr. Workshop on Neurobiology of Epilepsy appraisal: new systemic imaging technologies to study the brain in experimental models of epilepsy. Epilepsia. 2014;55(6):819-28. doi: 10.1111/epi.12642.

56. Gupta PK, Sayed N, Ding K, Agostini MA, Van Ness PC, Yablon S, Madden C, Mickey B, D'Ambrosio R, Diaz-Arrastia R. Subtypes of post-traumatic epilepsy: clinical, electrophysiological, and imaging features. J Neurotrauma. 2014;31(16):1439-43. doi: 10.1089/ neu.2013.3221.

57. Salo RA, Miettinen T, Laitinen T, Gröhn O, Sierra A. Diffusion tensor MRI shows progressive changes in the hippocampus and dentate gyrus after status epilepticus in rat - histological validation with Fourier-based analysis. Neuroimage. 2017;152:221-36. doi: 10.1016/j. neuroimage.2017.03.003.

58. Shultz SR, Cardamone L, Liu YR, Hogan RE, Maccotta L, Wright DK, Zheng $P$, Koe $A$, Gregoire MC, Williams JP, Hicks RJ, Jones NC, Myers DE, O'Brien TJ, Bouilleret V. Can structural or functional changes following traumatic brain injury in the rat predict epileptic outcome? Epilepsia. 2013;54(7):1240-50. doi: 10.1111/epi.12223.

59. Mishra AM, Bai X, Sanganahalli BG, Waxman SG, Shatillo O, Grohn O, Hyder F, Pitkänen $A$, Blumenfeld $H$. Decreased resting functional connectivity after traumatic brain injury in the rat. PLoS One. 2014;9(4):e95280. doi: 10.1371/journal.pone.0095280.

60. Liao W, Zhang Z, Pan Z, Mantini D, Ding J, Duan X, Luo C, Wang Z, Tan Q, Lu G, Chen H. Default mode network abnormalities in mesial temporal lobe epilepsy: a study combining fMRI and DTI. Hum Brain Mapp. 2011;32(6): 883-95. doi: 10.1002/hbm.21076.

61. Miller KJ. Broadband spectral change: evidence for a macroscale correlate of population firing rate? J Neurosci. 2010;30(19):6477-9. doi: 10.1523/JNEUROSCI.6401-09.2010.

62. Miller KJ, Honey CJ, Hermes D, Rao RP, denNijs M, Ojemann JG. Broadband changes in the cortical surface potential track activation of functionally diverse neuronal populations. Neuroimage. 2014;85 Pt 2:711-20. doi: 10.1016/j.neuroimage.2013.08.070.

63. Foster BL, Rangarajan V, Shirer WR, Parvizi J. Intrinsic and task-dependent coupling of neuronal population activity in human parietal cortex. Neuron. 2015;86(2):578-90. doi: 10.1016/j.neuron.2015.03.018.

64. Scott RC, Menendez de la Prida L, Mahoney JM, Kobow K, Sankar R, de Curtis M. WONOEP APPRAISAL: The many facets of epilepsy networks. Epilepsia. 2018;59(8):1475-83. doi: 10.1111/epi.14503.

65. Bragin A, Engel J Jr, Wilson CL, Fried I, Buzsáki G. High-frequency oscillations in human brain. Hippocampus. 1999;9(2):137-42. doi: 10.1002/(SICI)1098-1063(1999)9:2<137::AIDHIPO5>3.0.CO;2-0.

66. Bragin A, Engel J Jr, Wilson CL, Fried I, Mathern GW. Hippocampal and entorhinal cortex high-frequency oscillations $(100-500 \mathrm{~Hz})$ in human epileptic brain and in kainic acid-treated rats with chronic seizures. Epilepsia. 1999:40(2):127-37. doi: 10.1111/j.15281157.1999.tb02065.x.

67. Bragin A, Engel J Jr, Wilson CL, Vizentin E, Mathern GW. Electrophysiologic analysis of a chronic seizure model after unilateral hippocampal KA injection. Epilepsia. 1999;40(9):1210-21. doi: 10.1111/j.1528-1157.1999.tb00849.x.

68. Bragin A, Mody I, Wilson CL, Engel J Jr. Local generation of fast ripples in epileptic brain. 
J Neurosci. 2002;22(5):2012-21. doi: 10.1523/ JNEUROSCI.22-05-02012.2002.

69. Bragin A, Wilson CL, Engel J. Voltage Depth Profiles of High-frequency Oscillations after Kainic Acid-induced Status Epilepticus. Epilepsia. 2007;48:35-40.

70. Ponomarenko AA, Korotkova TM, Haas HL. High frequency $(200 \mathrm{~Hz})$ oscillations and firing patterns in the basolateral amygdala and dorsal endopiriform nucleus of the behaving rat. Behav Brain Res. 2003;141(2):123-9. doi: 10.1016/S0166-4328(02)00327-3.

71. Dzhala VI, Staley KJ. Mechanisms of fast ripples in the hippocampus. J Neurosci. 2004;24(40):8896-906. doi: 10.1523/JNEUROSCl.3112-04.2004.

72. Akiyama $T$, Otsubo $H$, Ochi $A$, Ishiguro $T$, Kadokura G, Ramachandrannair R, Weiss SK, Rutka JT, Carter Snead O $3^{\text {rd }}$. Focal cortical high-frequency oscillations trigger epileptic spasms: confirmation by digital video subdural EEG. Clin Neurophysiol. 2005;116(12):2819-25. doi: 10.1016/j.clinph.2005.08.029.
73. Jirsch JD, Dubeau F, Urrestarazu E, LeVan P, Gotman J. High frequency activity (100 to $500 \mathrm{hz}$ ) in areas of ictal onset and propagation in patients with focal seizures. Epilepsia. 2005;46 Suppl 8:267.

74. Foffani G, Uzcategui YG, Gal B, Menendez de la Prida L. Reduced spike-timing reliability correlates with the emergence of fast ripples in the rat epileptic hippocampus. Neuron. 2007;55(6): 930-41. doi: 10.1016/j.neuron.2007.07.040.

75. Ochi A, Otsubo H, Donner EJ, Elliott I, Iwata R, Funaki T, Akizuki $\mathrm{Y}$, Akiyama T, Imai K, Rutka JT, Snead OC $3^{\text {rd }}$. Dynamic changes of ictal high-frequency oscillations in neocortical epilepsy: using multiple band frequency analysis. Epilepsia. 2007;48(2):286-96.

76. Jacobs J, Zijlmans M, Zelmann R, Chatillon CE, Hall J, Olivier A, Dubeau F, Gotman J. High-frequency electroencephalographic oscillations correlate with outcome of epilepsy surgery. Ann Neurol. 2010;67(2):209-20. doi: 10.1002/ ana.21847.

77. Brázdil M, Halámek J, Jurák P, Daniel P, Kuba R, Chrastina J, Novák Z, Rektor I. Interictal high-frequency oscillations indicate seizure onset zone in patients with focal cortical dysplasia. Epilepsy Res. 2010;90(1-2):28-32. doi: 10.1016/j.eplepsyres.2010.03.003.

78. Melani F, Zelmann R, Mari F, Gotman J. Continuous High Frequency Activity: a peculiar SEEG pattern related to specific brain regions. Clin Neurophysiol. 2013;124(8):1507-16. doi: 10.1016/j.clinph.2012.11.016.

79. Bragin A, Wilson CL, Engel J. Spatial stability over time of brain areas generating fast ripples in the epileptic rat. Epilepsia. 2003;44(9): 1233-7.

80. Bragin A, Li L, Almajano J, Alvarado-Rojas C, Reid AY, Staba RJ, Engel J Jr. Pathologic electrographic changes after experimental traumatic brain injury. Epilepsia. 2016;57(5):735-45. doi: 10.1111/epi.13359.

81. Bragin A, Wilson CL, Almajano J, Mody I, Engel J Jr. High-frequency oscillations after status epilepticus: epileptogenesis and seizure genesis. Epilepsia. 2004;45(9):1017-23. doi: 10.1111/j.0013-9580.2004.17004.x.

\title{
Предотвращение эпилептогенеза как будущая стратегия терапии эпилепсии
}

\author{
Брагин А.Г. ${ }^{1}$
}

Эпилепсией страдают более 70 млн человек во всем мире. От 30 до 40\% больных резистентны к существующим лекарственным средствам. В статье описано современное состояние терапии эпилепсии и предложен возможный подход к превентивной терапии на ранних стадиях эпилептогенеза. Для прогнозирования развития эпилепсии на ее ранних стадиях нужны биомаркеры. Единственным приемлемым биомаркером эпилептогенеза следует признать патологические высокочастотные осцилляции. Однако главное ограничение метода - необходимость имплантации электродов для их регистрации. Одной из актуальнейших тем научных исследований эпилепсии представляется поиск неинвазивных биомаркеров эпилептогенеза. В свою очередь, в этой области существуют два потенциально интересных направления: поиск воспалительных биомаркеров в периферической крови и анализ различных параметров, которые дают визуализирующие методы. В этой публикации мы освещаем подходы к определению потенциальных биомаркеров эпилептогенеза с помощью магнитно-резонансной томографии. Некоторые из параметров магнитно-резонансной томографии коррелируют с наличием патологических высокочастотных осцилляций, могут косвенно отражать текущий воспалительный процесс в головном мозге и стать возможными биомаркерами эпилептогенеза.

Ключевые слова: эпилепсия, патологические высокочастотные осцилляции, биомаркеры эпилептогенеза, превентивная терапия

Для цитирования: Брагин АГ. Предотвращение эпилептогенеза как будущая стратегия терапии эпилепсии. Альманах клинической медицины. 2019;47(7):614-22. doi: 10.18786/2072-0505-201947-028.

Поступила 19.06.2019; принята к публикации 24.06.2019; опубликована онлайн 09.07.2019

\section{Финансирование}

Исследование проведено за счет средств Национальных институтов здоровья США (NIH), грант NS065877.

Брагин Анатолий Григорьевич - д-р биол. наук, науч. сотр. отделения неврологии Центра по эпилепсии'; ORCID: https://orcid.org/0000-0003$1207-8481$

$\triangle$ 90095, Калифорния, Лос-Анджелес, Вествуд Плаза, 710, Соединенные Штаты Америки. E-mail: abragin@mednet.ucla.edu
'Калифорнийский университет (Лос-Анджелес); 90095, Калифорния, Лос-Анджелес, Вествуд Плаза, 710, Соединенные Штаты Америки 